\title{
Growth-dependent recruitment of Pacific bluefin tuna Thunnus orientalis in the northwestern Pacific Ocean
}

\author{
Yosuke Tanaka*, Keisuke Satoh, Masayuki Iwahashi, Harumi Yamada \\ National Research Institute of Far Seas Fisheries, 5-7-1 Orido, Shimizu, Shizuoka City 424-8633, Shizuoka, Japan
}

\begin{abstract}
To estimate the survival process of Pacific bluefin tuna Thunnus orientalis during the larval period, estimated growth histories were compared between larvae collected in late spring and juveniles collected in the boreal summer of 2004, which were considered to be survivors of the larval cohorts. Larval tuna (3.3 to $9.6 \mathrm{~mm}$ standard length, SL) were collected from mid-May to early June around the Ryukyu Islands, northwestern Pacific Ocean, and juvenile tuna were collected offshore of Kochi and Nagasaki prefectures in July-August. Preflexion, flexion and postflexion larvae were collected, and their ages ranged from 4 to $18 \mathrm{~d}$. Back-calculated SLs by the biological intercept method showed that larval tuna in the postflexion phase were larger-at-age than preflexion and flexion larvae, suggesting that only larger and faster growing larvae were able to survive to the postflexion phase. The logarithms of otolith radii (ln OR: proportional to SL) of larvae with slower growth and development were smaller than the minimum ln OR of surviving juvenile tuna, which indicated the smallest possible size required for larvae to successfully recruit to the fishery. These results indicate that the survival of larvae of Pacific bluefin tuna depends largely on size and growth rates during early life history.
\end{abstract}

KEY WORDS: Growth · Survival · Recruitment · Otolith · Pacific bluefin tuna Resale or republication not permitted without written consent of the publisher

\section{INTRODUCTION}

Pacific bluefin tuna Thunnus orientalis is distributed widely in the North Pacific Ocean (see Collette 1999) and is one of the most important fisheries species in Japan. Recently, Collette (1999) considered Pacific bluefin tuna and Atlantic bluefin tuna T. thynnus to be separate species on the basis of morphology and molecular data. The spawning grounds of the Pacific bluefin tuna form in the area between the Philippines and the Ryukyu Islands in the northwestern Pacific Ocean from April to June, and in the Sea of Japan in August (Yabe et al. 1966, Ueyanagi 1969, Okiyama 1974, Kitagawa et al. 1995). Larvae hatched in the northwestern Pacific Ocean are carried by the Kuroshio Current and juvenile bluefin tuna are transported to near the coast of Japan, where they are caught by troll fisheries and are used as fingerlings for aquaculture. Although eco-physiological studies on the early life stages of Pacific bluefin tuna have been conducted using laboratory-reared bluefin tuna (Kaji et al. 1996, Miyashita et al. 1998, Itoh et al. 2000, Miyashita et al. 2000, Miyashita et al. 2001), studies on the early life stages of Pacific bluefin tuna in the field are rare.

Marine fish species generally produce a huge number of small pelagic eggs, and mortality during the egg, larval and juvenile stage is considered to be the main cause of interannual variability in recruitment in many species (Bailey \& Houde 1989). Growth of larvae and juveniles is one of the most important factors for their survival. In several fish species, larvae with lower growth rates have been reported to have a higher mortality (Hovenkamp 1992, Meekan \& Fortier 1996, Searcy \& Sponaugle 2001, Takasuka et al. 2003, Takahashi \& Watanabe 2004), because bigger larvae have a 


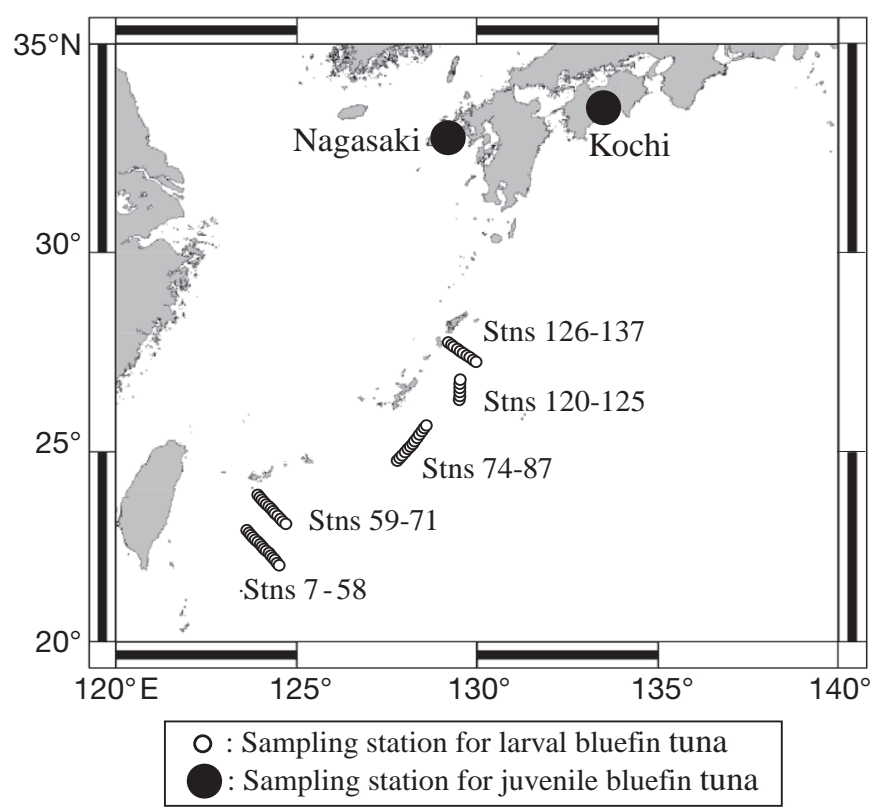

Fig. 1. Thunnus orientalis. Stations sampled for larval and juvenile bluefin tuna in the northwestern Pacific Ocean

higher tolerance to starvation and a greater ability to escape from predators than smaller larvae (Anderson 1988, Miller et al. 1988, Bailey \& Houde 1989). The target species in these studies were flatfish, cod, coral reef fishes and clupeoids, which have relatively low growth rates and a long pelagic period in their early life stages, with the exception of larval bluefish Pomatomus saltatrix that has a relatively high growth potential (Hare \& Cowen 1997). Scombrid fishes including Pacific bluefin tuna are generally considered to have survival strategies in the early life stages characterized by large prey and fast growth (Hunter 1981, Tanaka et al. 1996). Scombrids have a high growth rate in the larval stages, and this growth is potentially variable depending on water temperature and food availability, implying that small variations in larval growth may induce broad variations in cumulative mortality and recruitment of the stock. We examined the hypothesis that growth during the early larval period is a key factor in the survival process of Pacific bluefin tuna larvae.

Growth history of individual fish is recorded in the otolith (Degens et al. 1969, Dunkelberger et al. 1980, Watanabe et al. 1982, Mugiya 1987). In this study, individual growth histories of larval bluefin tuna were back-calculated from the otolith increment width and compared to growth histories of juvenile bluefin tuna collected in the coastal zone of Japan. These juvenile bluefin tuna were considered to be survivors of the sampled larval population. The objectives of the present study were to (1) examine growth of Pacific bluefin tuna in the larval stage based on otolith microstructure analysis, and (2) estimate the survival process in relation to growth during the larval period by comparison with juvenile bluefin tuna.

\section{MATERIALS AND METHODS}

Collection of larval bluefin tuna. Pacific bluefin tuna larvae were collected by surface trawls in the northwestern Pacific Ocean aboard RV 'Shunyo-Maru' (Fig. 1). Sampling was done during night-time at 62 stations from 14 May to 7 June 2004 (Fig. 1, Table 1) using a $2 \mathrm{~m}$ diameter net with a $330 \mu \mathrm{m}$ mesh. At each station, the net was towed at the sea surface beside the hull for $10 \mathrm{~min}$ at a speed of approximately 1.5 knots. The volume of water filtered was calculated from the mouth area of the net multiplied by distance traveled, which was measured by a calibrated flowmeter attached to the net mouth. Some of the tuna larvae were frozen $\left(-70^{\circ} \mathrm{C}\right)$ onboard immediately after being sorted. The rest of the sample was fixed and preserved in $99.5 \%$ ethanol. At each station, sea surface temperature (SST) was observed by direct measurement ( $0 \mathrm{~m}$ depth) and CTD measurement (>3 m depth with $1 \mathrm{~m}$ depth pitch); mean water temperature $<10 \mathrm{~m}$ depth was used to represent ambient water temperature for larvae collected at the station, because water temperature at depths shallower than $2 \mathrm{~m}$ (ring diameter) may be influenced by weather conditions such as rain and wind.

Standard length (SL) of tuna larvae were measured to the nearest $0.1 \mathrm{~mm}$ with a micrometer, and developmental phases (preflexion, flexion and postflexion phase) of larvae were identified according to Kendall et al. (1984) for a maximum of 100 larvae at each station. Laboratory-reared larvae were used to determine the effect of ethanol fixation on shrinkage of SL (Kobayashi unpubl. data). Fertilized eggs of bluefin tuna were provided by Ohshima Experiment Station, Fisheries Laboratory of Kinki University, and reared at Maizuru Fisheries Research Station, Kyoto University. Both wild-caught and laboratory-reared larvae were preserved in $99.5 \%$ ethanol for 4 to 5 mo. The relationship between SL before and after fixation was expressed by the following equation (range: 3.3 to $40.9 \mathrm{~mm} \mathrm{SL):}$

$$
\begin{gathered}
\mathrm{SL}_{\text {before }}=0.98 \mathrm{SL}_{\mathrm{after}}+0.68 \\
\mathrm{r}^{2}=0.96, \mathrm{n}=128
\end{gathered}
$$

which was used to correct SL of fixed larvae, where $\mathrm{SL}_{\text {before }}$ and $\mathrm{SL}_{\text {after }}$ were SL of tuna larvae before and after fixation, respectively. The SL of frozen larvae were not corrected.

Otolith microstructure analysis of larval bluefin tuna. 349 fish (136 in preflexion, 124 in flexion and 89 
Table 1. Thunnus orientalis. Sampling dates in 2004, location, water temperature $\left(\mathrm{WT},{ }^{\circ} \mathrm{C}\right)$, number of collected larvae, density (no. of ind. $1000 \mathrm{~m}^{-3}$ ), mean standard length (SL in $\mathrm{mm}$ ), standard deviation (SD) and range of SL

\begin{tabular}{|c|c|c|c|c|c|c|c|c|c|}
\hline Stn & Date & Lat. (N) & Long. (E) & WT & $\mathrm{n}$ & Density & Mean & $\mathrm{SD}$ & Range \\
\hline 7 & 14 May & $21^{\circ} 59$ & $124^{\circ} 59$ & 28.2 & 0 & 0.0 & & & \\
\hline 8 & 14 May & $22^{\circ} 04$ & $124^{\circ} 54$ & 28.4 & 0 & 0.0 & & & \\
\hline 9 & 14 May & $22^{\circ} 10$ & $124^{\circ} 49$ & 28.4 & 0 & 0.0 & & & \\
\hline 10 & 14 May & $22^{\circ} 15$ & $124^{\circ} 44$ & 26.1 & 5 & 3.0 & 5.48 & 0.10 & $5.38-5.58$ \\
\hline 11 & 15 May & $22^{\circ} 20$ & $124^{\circ} 39$ & 26.4 & 2 & 1.1 & 4.55 & & $4.99-4.10$ \\
\hline 12 & 15 May & $22^{\circ} 25$ & $124^{\circ} 34$ & 25.9 & 19 & 12.0 & 5.56 & 0.28 & $4.98-5.97$ \\
\hline 48 & 21 May & $23^{\circ} 59$ & $124^{\circ} 00$ & 28.4 & 2 & 1.0 & 6.93 & & $6.26-7.60$ \\
\hline 49 & 21 May & $23^{\circ} 54$ & $124^{\circ} 05$ & 28.3 & 9 & 4.8 & 6.19 & 0.47 & $5.38-6.90$ \\
\hline 50 & 21 May & $23^{\circ} 48$ & $124^{\circ} 10$ & 28.1 & 16 & 8.8 & 6.82 & 0.84 & $5.38-8.90$ \\
\hline 51 & 21 May & $23^{\circ} 43$ & $124^{\circ} 15$ & 28.1 & 4 & 2.3 & 6.58 & 1.01 & $5.10-7.40$ \\
\hline 52 & 21 May & $23^{\circ} 38$ & $124^{\circ} 21$ & 28.4 & 0 & 0.0 & & & \\
\hline 53 & 23 May & $23^{\circ} 33$ & $124^{\circ} 25$ & 28.3 & 4 & 2.5 & 6.57 & 0.61 & $5.87-7.34$ \\
\hline 54 & 23 May & $23^{\circ} 28$ & $124^{\circ} 31$ & 28.0 & 1 & 0.6 & 6.46 & & \\
\hline 55 & 23 May & $23^{\circ} 22$ & $124^{\circ} 36$ & 27.9 & 2 & 1.2 & 7.10 & & $6.50-7.70$ \\
\hline 56 & 23 May & $23^{\circ} 17$ & $124^{\circ} 41$ & 27.8 & 4 & 2.3 & 5.71 & 1.14 & $4.99-7.40$ \\
\hline 57 & 23 May & $23^{\circ} 12$ & $124^{\circ} 47$ & 27.8 & 1 & 0.6 & 4.20 & & \\
\hline 58 & 23 May & $23^{\circ} 08$ & $124^{\circ} 51$ & 27.8 & 10 & 5.0 & 4.81 & 0.26 & $4.30-5.20$ \\
\hline 59 & 27 May & $22^{\circ} 59$ & $124^{\circ} 00$ & 27.8 & 0 & 0.0 & & & \\
\hline 60 & 27 May & $22^{\circ} 53$ & $124^{\circ} 05$ & 27.4 & 25 & 15.7 & 6.11 & 0.51 & $5.10-7.20$ \\
\hline 61 & 27 May & $22^{\circ} 49$ & $124^{\circ} 10$ & 27.5 & 0 & 0.0 & & & \\
\hline 62 & 27 May & $22^{\circ} 44$ & $124^{\circ} 16$ & 27.6 & 0 & 0.0 & & & \\
\hline 63 & 27 May & $22^{\circ} 38$ & $124^{\circ} 21$ & 26.9 & 0 & 0.0 & & & \\
\hline 64 & 28 May & $22^{\circ} 32$ & $124^{\circ} 26$ & 27.4 & 1 & 0.6 & 6.16 & & \\
\hline 65 & 28 May & $22^{\circ} 28$ & $124^{\circ} 31$ & 26.4 & 1 & 0.6 & 6.9 & & \\
\hline 66 & 28 May & $22^{\circ} 23$ & $124^{\circ} 36$ & 26.1 & 6 & 3.3 & 7.04 & 0.38 & $6.50-7.63$ \\
\hline 67 & 28 May & $22^{\circ} 17$ & $124^{\circ} 41$ & 26.6 & 7 & 4.0 & 7.10 & 0.44 & $6.40-7.60$ \\
\hline 68 & 28 May & $22^{\circ} 12$ & $124^{\circ} 46$ & 26.2 & 6 & 2.9 & 6.09 & 0.90 & $4.40-6.90$ \\
\hline 69 & 29 May & $22^{\circ} 07$ & $124^{\circ} 51$ & 26.1 & 2 & 1.1 & 5.68 & & $5.28-6.07$ \\
\hline 70 & 29 May & $22^{\circ} 02$ & $124^{\circ} 56$ & 25.9 & 18 & 10.1 & 5.68 & 0.61 & $4.70-6.70$ \\
\hline 71 & 29 May & $21^{\circ} 59$ & $125^{\circ} 00$ & 25.4 & 5 & 2.7 & 6.03 & 0.91 & $4.99-7.40$ \\
\hline 74 & 30 May & $25^{\circ} 00$ & $128^{\circ} 00$ & 25.7 & 0 & 0.0 & & & \\
\hline 75 & 30 May & $25^{\circ} 05$ & $128^{\circ} 05$ & 25.8 & 0 & 0.0 & & & \\
\hline 76 & 30 May & $25^{\circ} 10$ & $128^{\circ} 10$ & 25.7 & 0 & 0.0 & & & \\
\hline 77 & 30 May & $25^{\circ} 15$ & $128^{\circ} 15$ & 25.5 & 0 & 0.0 & & & \\
\hline 78 & 30 May & $25^{\circ} 20$ & $128^{\circ} 21$ & 25.4 & 0 & 0.0 & & & \\
\hline 79 & 30 May & $25^{\circ} 25$ & $128^{\circ} 26$ & 28.3 & 21 & 12.3 & 6.27 & 0.59 & $5.60-7.70$ \\
\hline 80 & 31 May & $25^{\circ} 31$ & $128^{\circ} 31$ & 27.2 & 0 & 0.0 & & & \\
\hline 81 & 31 May & $25^{\circ} 35$ & $128^{\circ} 37$ & 26.0 & 4 & 2.6 & 6.25 & 0.70 & $5.30-7.00$ \\
\hline 82 & 31 May & $25^{\circ} 41$ & $128^{\circ} 41$ & 28.4 & 2 & 1.1 & 6.60 & & $5.90-7.30$ \\
\hline 83 & 31 May & $25^{\circ} 46$ & $128^{\circ} 47$ & 26.1 & 3 & 1.7 & 8.43 & 1.07 & $7.50-9.60$ \\
\hline 84 & 31 May & $25^{\circ} 51$ & $128^{\circ} 52$ & 28.6 & 13 & 7.3 & 7.27 & 0.92 & $5.50-8.40$ \\
\hline 85 & 1 June & $25^{\circ} 57$ & $128^{\circ} 57$ & 28.8 & 7 & 4.0 & 8.00 & 1.17 & $7.30-9.30$ \\
\hline 86 & 1 June & $26^{\circ} 02$ & $129^{\circ} 02$ & 27.8 & 3 & 1.8 & 7.57 & 1.01 & $6.40-8.20$ \\
\hline 87 & 1 June & $26^{\circ} 07$ & $129^{\circ} 07$ & 28.1 & 596 & 349.3 & 5.42 & 0.47 & $4.01-8.51$ \\
\hline 120 & 5 June & $26^{\circ} 20$ & $129^{\circ} 40$ & 26.0 & 317 & 175.5 & 4.07 & 0.23 & $3.30-4.61$ \\
\hline 121 & 5 June & $26^{\circ} 27$ & $129^{\circ} 40$ & 25.0 & 36 & 19.2 & 4.34 & 0.26 & $3.83-4.94$ \\
\hline 122 & 5 June & $26^{\circ} 34$ & $129^{\circ} 39$ & 25.9 & 0 & 0.0 & & & \\
\hline 123 & 5 June & $26^{\circ} 41$ & $129^{\circ} 40$ & 26.4 & 4 & 2.0 & 3.94 & 0.66 & $3.32-4.87$ \\
\hline 124 & 5 June & $26^{\circ} 48$ & $129^{\circ} 39$ & 25.9 & 109 & 58.1 & 3.68 & 0.19 & $3.25-4.61$ \\
\hline 125 & 5 June & $26^{\circ} 55$ & $129^{\circ} 39$ & 27.9 & 2 & 1.1 & 3.64 & & $3.60-3.70$ \\
\hline 126 & 6 June & $27^{\circ} 00$ & $130^{\circ} 00$ & 26.6 & 1 & 0.5 & 3.64 & & \\
\hline 127 & 6 June & $27^{\circ} 06$ & $129^{\circ} 55$ & 27.6 & 0 & 0.0 & & & \\
\hline 128 & 6 June & $27^{\circ} 10$ & $129^{\circ} 50$ & 25.8 & 0 & 0.0 & & & \\
\hline 129 & 6 June & $27^{\circ} 15$ & $129^{\circ} 44$ & 28.4 & 0 & 0.0 & & & \\
\hline 130 & 6 June & $27^{\circ} 21$ & $129^{\circ} 39$ & 28.5 & 0 & 0.0 & & & \\
\hline 131 & 6 June & $27^{\circ} 26$ & $129^{\circ} 33$ & 27.1 & 5 & 2.6 & 3.96 & 0.12 & $3.80-4.10$ \\
\hline 132 & 7 June & $27^{\circ} 31$ & $129^{\circ} 28$ & 27.9 & 0 & 0.0 & & & \\
\hline 133 & 7 June & $27^{\circ} 36$ & $129^{\circ} 22$ & 28.6 & 0 & 0.0 & & & \\
\hline 134 & 7 June & $27^{\circ} 41$ & $129^{\circ} 17$ & 26.2 & 0 & 0.0 & & & \\
\hline 135 & 7 June & $27^{\circ} 47$ & $129^{\circ} 12$ & 25.9 & 0 & 0.0 & & & \\
\hline 136 & 7 June & $27^{\circ} 52$ & $129^{\circ} 07$ & 26.4 & 0 & 0.0 & & & \\
\hline 137 & 7 June & $28^{\circ} 00$ & $128^{\circ} 59$ & 25.9 & 0 & 0.0 & & & \\
\hline
\end{tabular}


in postflexion phase) were used for otolith microstructure analysis. Each sagitta was removed, placed on a slide and covered with glycerol. Enumeration of increments and measurements of increment width $(\mu \mathrm{m})$ and

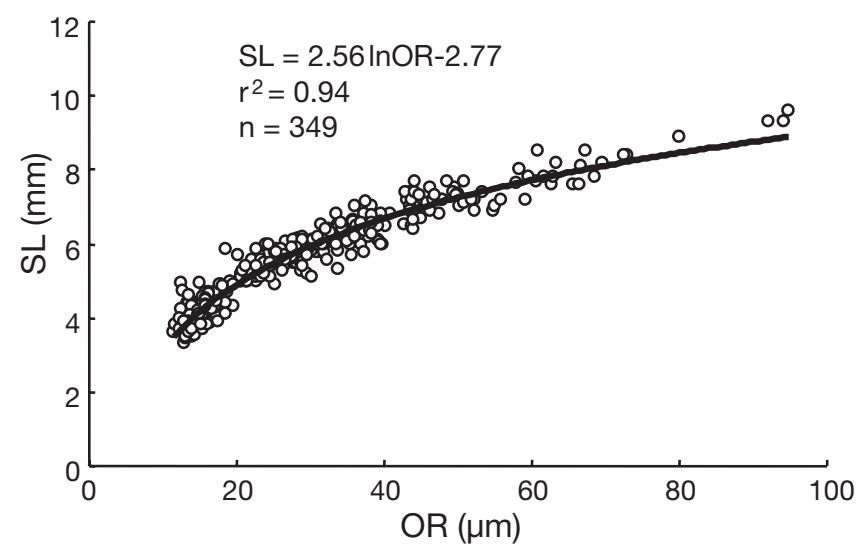

Fig. 2. Thunnus orientalis. Relationship between otolith radius (OR) and standard length (SL) of larvae otolith radius $(\mu \mathrm{m})$ were conducted along the longest growth axis in the postrostrum of each otolith under a light microscope at $1000 \times$ magnification with an otolith measurement system (RATOC System Engineering). Itoh et al. (2000) reported that increments are formed daily and that the first increment is formed around $4 \mathrm{~d}$ after hatching, corresponding to the onset of feeding. Age and hatch date of larvae were estimated according to Itoh et al. (2000).

The size at age of each larva was back-calculated based on the relationship between otolith radius (OR) and SL. SL was proportional to the logarithm of OR (Fig. 2). SL was back-calculated for each larva by the biological intercept method (Campana 1990, Campana \& Jones 1992) using parameters from the following equations:

$$
\begin{aligned}
\mathrm{SL}_{1} & =a \operatorname{lnOR} \mathrm{R}_{1}+b \\
\mathrm{SL}_{\text {capture }} & =a \operatorname{lnOR} \mathrm{R}_{\text {capture }}+b
\end{aligned}
$$

where $\mathrm{SL}_{1}$ is the $\mathrm{SL}(\mathrm{mm})$ at first-feeding, and $\mathrm{OR}_{1}$ is the otolith radius $(\mu \mathrm{m})$ of the first increment of each individual fish. For $\mathrm{SL}_{1}$, the value $3.3 \mathrm{~mm}$ was used, which is the SL at first-feeding reported by Kaji et al. (1996). Based on back-calculated SL, the growth rate $\left(\mathrm{mm} \mathrm{d}^{-1}\right)$ of 3 growth intervals, 5 to 7,8 to 10 and 11 to $13 \mathrm{~d}$ after hatching were calculated.

Repeated measures analysis (PROC MIXED procedure, SAS software) was used to examine differences in longitudinal and auto-correlated data sets of back-calculated SL and growth rate among developmental phases (Chambers \& Miller 1995). The significance level for these post hoc tests was set at $\alpha=0.05 \times 3^{-1}$, where the denominator is the number of comparisons among groups per growth interval.

Otolith microstructure analysis of juvenile bluefin tuna. Juvenile bluefin tuna were caught by troll fisheries in the coastal areas off Kochi and Nagasaki prefectures in July and August 2004 (Fig. 1 and Table 2). To avoid sizeselective collection, juvenile bluefin tuna were collected using lures that were as small as possible (ca. $5 \mathrm{~cm}$ ) and the sampling period fully covered the fisheries season for juvenile bluefin tuna. Sagitta of each juvenile bluefin tuna was extracted after the fork length (FL) was measured to the nearest $1 \mathrm{~mm}$. Extracted otoliths were mounted on a glass slide using nail enamel, with the flat side of the sagitta facing the glass
Fig. 3. Thunnus orientalis. Estimated hatch date composition of (A) larval and (B) juvenile bluefin tuna. Open, shaded and closed bars indicate larvae in the preflexion, flexion and postflexion phases, respectively. Arrow shows range of hatch dates of juvenile samples used in comparison with larval growth 
Table 2. Thunnus orientalis. Juvenile collection data from waters off Kochi and Nagasaki prefectures in 2004. FL: fork length

\begin{tabular}{|lcrcc|}
\hline & $\begin{array}{c}\text { Sampling } \\
\text { period }\end{array}$ & $\mathrm{n}$ & $\begin{array}{c}\text { Range of } \\
\text { FL (mm) }\end{array}$ & $\begin{array}{c}\text { Range of } \\
\text { age (d) }\end{array}$ \\
\hline Kochi & 15 Jul-17 Aug & 104 & $167-300$ & $54-89$ \\
Nagasaki & 27 Jul-23 Aug & 75 & $193-319$ & $57-107$ \\
\hline
\end{tabular}

surface. The core region was etched by touching it with a small piece of paper soaked in $3 \mathrm{~N} \mathrm{HCl}$. After a few seconds, the otolith was rinsed with distilled water, and the progress of the etching was observed under a microscope. This process was repeated until all increments around the core region were exposed. Using a compound microscope with transmitted light and a magnification of $500 \times$, enumeration of the increments and measurements of increment width $(\mu \mathrm{m})$ and otolith radius $(\mu \mu \mathrm{m})$ were recorded using the otolith measurement system. Otolith increments were counted once for each individual.

Comparison of growth history between larval and juvenile bluefin tuna. We could not back-calculate the growth histories of juvenile bluefin tuna because the OR/SL relationship from larval to juvenile tuna has not been described. Since SL was positively correlated with the logarithm of OR (ln OR) during the larval stage aged from 5 to $18 \mathrm{~d}$ (Fig. 2), we compared the growth histories between larval and juvenile bluefin tuna in terms of ln OR in the larval stage in the present study. Modes of the distribution of ln OR of larval and juvenile bluefin tuna at each age were tested using Mann-Whitney $U$-tests.

\section{RESULTS}

\section{Developmental phases and standard length of larval bluefin tuna}

1273 larval bluefin tuna were collected at 35 stations (Table 1). The density of larvae (no. of ind. $1000 \mathrm{~m}^{-3}$ ) ranged from 0 to 349.3 , and mean water temperature ranged from 25.0 to $28.8^{\circ} \mathrm{C}$. Larval bluefin tuna ranged in size from 3.3 to $9.6 \mathrm{~mm}$ SL. Estimated hatch dates ranged from 2 May to 1 June (Fig. 3).

Developmental phases of larvae were categorized into 11 size classes of $0.5 \mathrm{~mm}$ intervals (Fig. 4A) and into 12 age classes of $1 \mathrm{~d}$ intervals (Fig. 4B). The shift from the preflexion to flexion phase was first noted in the 3.5 to $4.0 \mathrm{~mm}$ size class (Fig. $4 \mathrm{~A}$ ). The proportion by number of the preflexion phase decreased with growth up to $6.0 \mathrm{~mm}$. Flexion larvae were observed up to the 7.0 to $7.5 \mathrm{~mm}$ size class. Postflexion larvae were first noted in the 6.0 to $6.5 \mathrm{~mm}$ size class. Age in days of the collected larvae ranged from 5 to $18 \mathrm{~d}$. The proportion of preflexion larvae sharply decreased in the $9 \mathrm{~d}$ age class (Fig. 4B). The shift from the preflexion to flexion phase was first noted in the $7 \mathrm{~d}$ age class. Postflexion larvae were first noted in the $10 \mathrm{~d}$ age class, and the proportion gradually increased until the $14 \mathrm{~d}$ age class.

\section{Larval growth history and growth rate}

Because mean water temperature ranged from 25.0 to $28.8^{\circ} \mathrm{C}$, back-calculated SLs were compared between larvae collected from stations with high water temperatures $\left(27.2\right.$ to $28.8^{\circ} \mathrm{C}, 19$ stations) and low water temperatures $\left(25.0\right.$ to $26.6^{\circ} \mathrm{C}, 16$ stations $)$ (Fig. 5). There were significant differences between growth histories of larvae from stations with high and low water temperature (temperature $\times$ age, $F=2.46$, $\mathrm{p}=0.006)$ and the significant difference was detected only at $7 \mathrm{~d}$. Mean SL $( \pm \mathrm{SD})$ of larvae at $7 \mathrm{~d}$ after hatching at stations with high and low water temperature
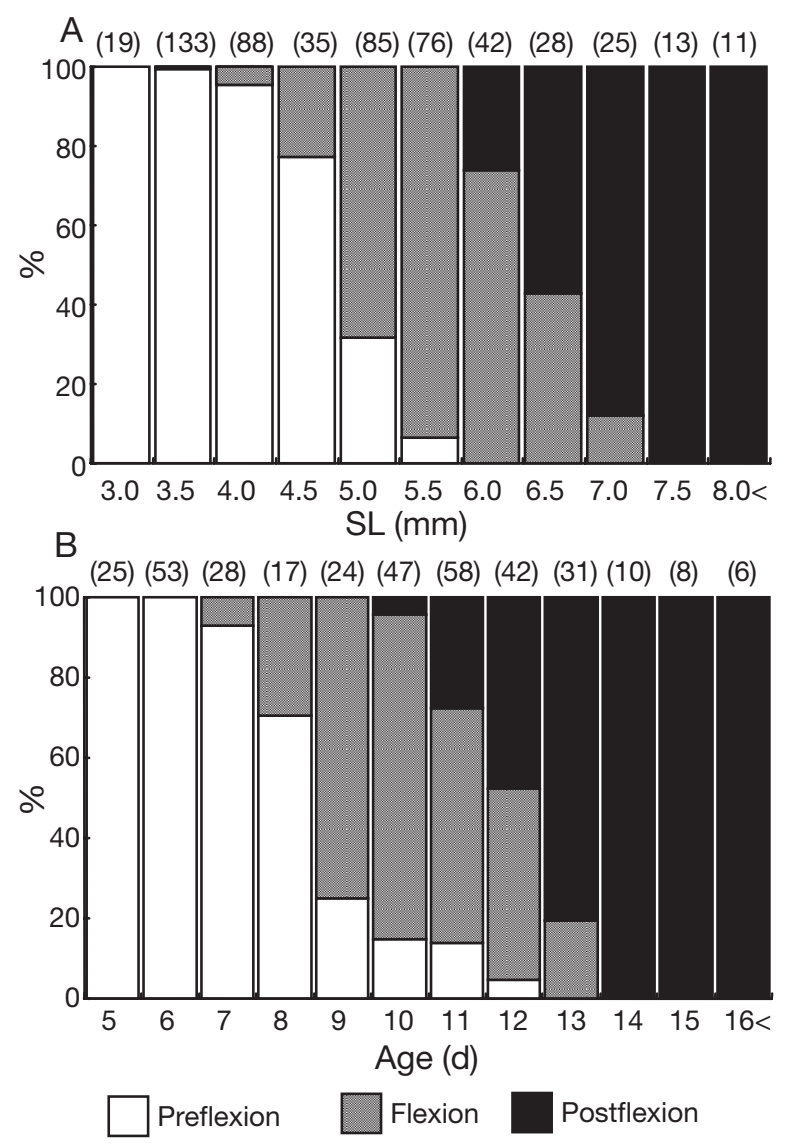

Fig. 4. Thunnus orientalis. Proportion (\%) by number of larvae in the preflexion, flexion and postflexion phases in each (A) size and (B) age class. Numbers of analyzed fish given in parentheses 


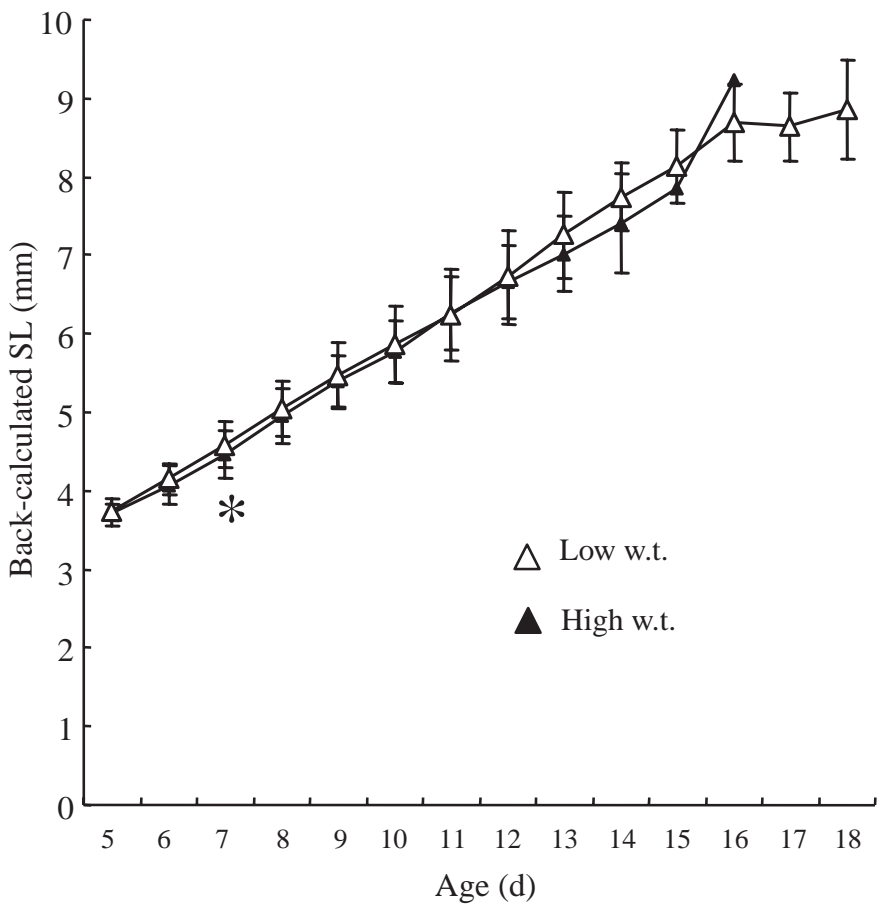

Fig. 5. Thunnus orientalis. Mean back-calculated SL \pm SD of larvae collected from stations with high $\left(27.2\right.$ to $\left.28.8^{\circ} \mathrm{C}\right)$ and low $\left(25.0\right.$ to $\left.26.6^{\circ} \mathrm{C}\right)$ water temperature (w.t.). $*$ : significant difference at $\mathrm{p}<0.01$

were $4.46 \pm 0.31$ and $4.58 \pm 0.29 \mathrm{~mm}$, respectively. Although we could not examine the water temperature experienced by the analyzed larvae (see 'Discussion'), growth histories of larvae were not found to be affected by mean water temperature at the sampling stations and therefore samples were combined to increase sample sizes.

Larval growth histories were significantly different among developmental phases (phase $\times$ age, $F=52.09$, $\mathrm{p}<0.001$, Fig. 6). The back-calculated SL of preflexion larvae after $6 \mathrm{~d}$ was significantly smaller than that of larvae in the flexion and postflexion phases at catch. The back-calculated SL of larvae in the flexion phase showed a similar trend to larvae in the postflexion phase until Day 8. Significant differences between the back-calculated SL of larvae in the flexion and postflexion phase occurred at approximately $5 \mathrm{~mm}$ on Day 8 . Afterward this time, the SL of larvae in the postflexion phase was significantly larger than larvae in the flexion phase, and finally reached 9.6 mm SL on Day 17 .

The growth rates of larvae were significantly different among the 3 developmental phases (phase $\times$ growth interval, $F=12.55, \mathrm{p}<0.001$, Fig. 7 ). For the 5 to $7 \mathrm{~d}$ growth interval, the distributions of growth rate of larvae in the flexion and postflexion phases were included within the range of the growth rate in the preflexion phase, and significant differences were not detected. For the 8 to 10 d interval, the growth rate in the postflexion phase was significantly higher than those in both the preflexion and flexion phases. For the 11 to $13 \mathrm{~d}$ interval, growth rates in the preflexion and flexion phase were significantly lower than that of the postflexion phase.

\section{Comparison of growth history between larval and juvenile bluefin tuna}

Because ages-at-catch and OR of juvenile bluefin tuna between 6 to $13 \mathrm{~d}$ of age were not significantly different between the 2 sampling locations, i.e. Kochi and Nagasaki (Mann-Whitney $U$-test, p > 0.05), hatch dates of juvenile bluefin tuna from the 2 sampling stations were combined. The hatch date of juvenile bluefin tuna ranged between 1 April and 15 June 2004 and peaked in late May (Fig. 3B). Since the hatch date of larvae ranged between 2 May and 1 June, we used data from otoliths of juvenile bluefin tuna which had hatch dates corresponding to those of the larvae. Ln OR of larvae in each developmental phase in 8 age classes from Days 6 to 13 (Fig. 4B) were used for comparison with those of juvenile bluefin tuna. The diameters of the first increments in otoliths from larvae in all developmental phases were not significantly different from those of juvenile bluefin tuna (KruskalWallis test, $\mathrm{p}>0.05$ ).

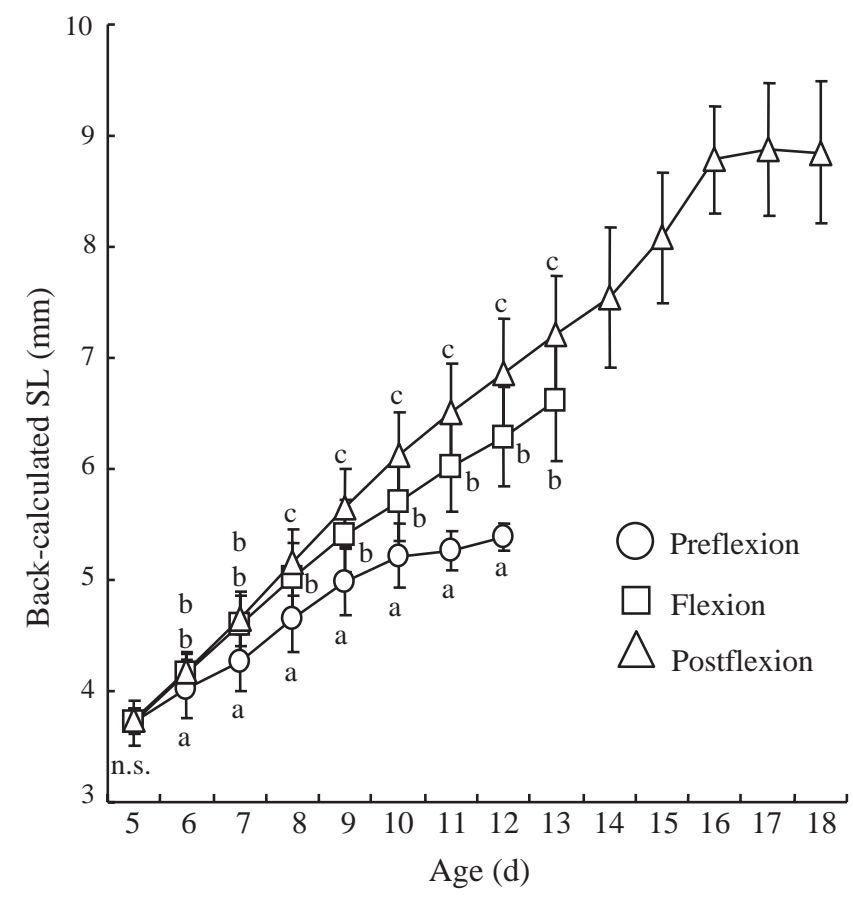

Fig. 6. Thunnus orientalis. Mean back-calculated SL \pm SD of larvae in the 3 developmental phases at catch: preflexion, flexion and postflexion. a,b,c: significant differences at each age; n.s.: not significant 


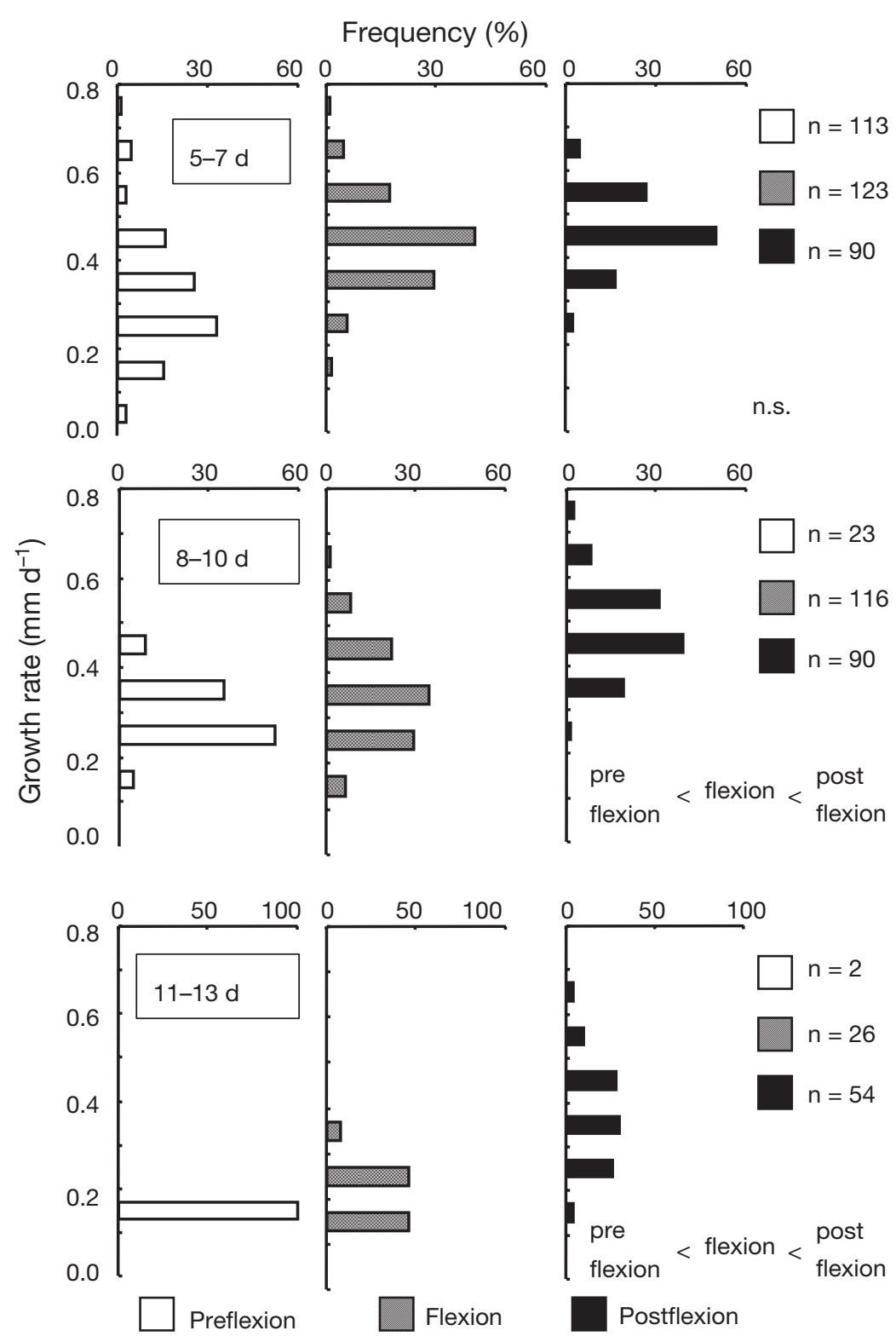

Fig. 7. Thunnus orientalis. Frequency distributions of growth rates $\left(\mathrm{mm} \mathrm{d}^{-1}\right)$ in the 3 developmental phases at catch (preflexion, flexion and postflexion) in growth intervals between 5-7, 8-10 and 11-13 d. Results of post-hoc tests shown at each growth interval. ns: not significant

Frequency distributions of ln OR of larvae in the preflexion, flexion and postflexion phases and juvenile tuna at Days 6, 7, 8 and 9 are shown in Fig. 8 and at Days 10, 11, 12 and 13 in Fig. 9. The mode of $\ln$ OR in juvenile bluefin tuna was comparable to that in the preflexion phase at Day 6. After Day 7, modes of ln OR in juvenile bluefin tuna increased and were significantly larger than those in the larvae (Mann-Whitney $U$-test, $\mathrm{p}<0.01$ ). After Day 10, differences between the modes of larval and juvenile bluefin tuna were conspicuous. The proportion by stage-specific number of larvae in the preflexion phase within the range of juvenile bluefin tuna was
$100 \%$ at Day 6 , and the proportion decreased to $0.0 \%$ at Day 11 (Table 3). The proportion in the flexion phase was $100 \%$ at Day 8 and decreased to $10.0 \%$ at Day 12. The proportion in the postflexion phase showed relatively higher values than those in the preflexion and flexion phase. The proportion in the postflexion was $100 \%$ at Day 10 and $80.0 \%$ at Day 13.

\section{DISCUSSION}

\section{Growth of larval bluefin tuna in the field}

Pacific bluefin tuna in the postflexion phase grew to approximately $3.8 \mathrm{~mm}$ SL by Day $5,6.1 \mathrm{~mm}$ SL by Day 10, and $8.0 \mathrm{~mm}$ SL by Day 15 - as determined by back-calculation using the biological intercept method - and the mode of the growth rate was between 0.3 to $0.5 \mathrm{~mm} \mathrm{~d}^{-1}$. The mean growth rate of populations based on linear regression was $0.32 \mathrm{~mm} \mathrm{~d}^{-1}$ for southern bluefin tuna Thunnus maccoyii (Jenkins \& Davis 1990), and $0.47 \mathrm{~mm} \mathrm{~d}^{-1}$ for yellowfin tuna $T$. albacares (Lang et al. 1994). Atlantic bluefin tuna T. thynnus grew to about $6.0 \mathrm{~mm}$ SL in $10 \mathrm{~d}$ (Brothers et al. 1983, Scott et al. 1993). Thus, the growth of larval Pacific bluefin tuna is similar to that in early life stages of other Thunnus species.

Growth histories based on otolith microstructure analysis were significantly different among the developmental phase at catch. The back-calculated SLs of larvae in the postflexion phase at catch in each age class were significantly larger than those of larvae in the preflexion and flexion phases. Growth retardation occurred in larvae in the preflexion phase at Day 6 at $4 \mathrm{~mm}$ SL and in the flexion phase at Day 8 at $5 \mathrm{~mm}$ SL (Fig. 6). The frequency distributions of growth rates of larvae in the postflexion phase shifted towards higher values relative to the preflexion phase for the 5 to $7 \mathrm{~d}$ growth interval and to the flexion phase for the 8 to $10 \mathrm{~d}$ growth interval. These results suggest that only larvae with a high growth rate developed to the postflexion phase.

It has been reported that food availability and ambient water temperature influence larval growth (e.g. Govoni et al. 1985, Folkvord et al. 2000, Takahashi \& 


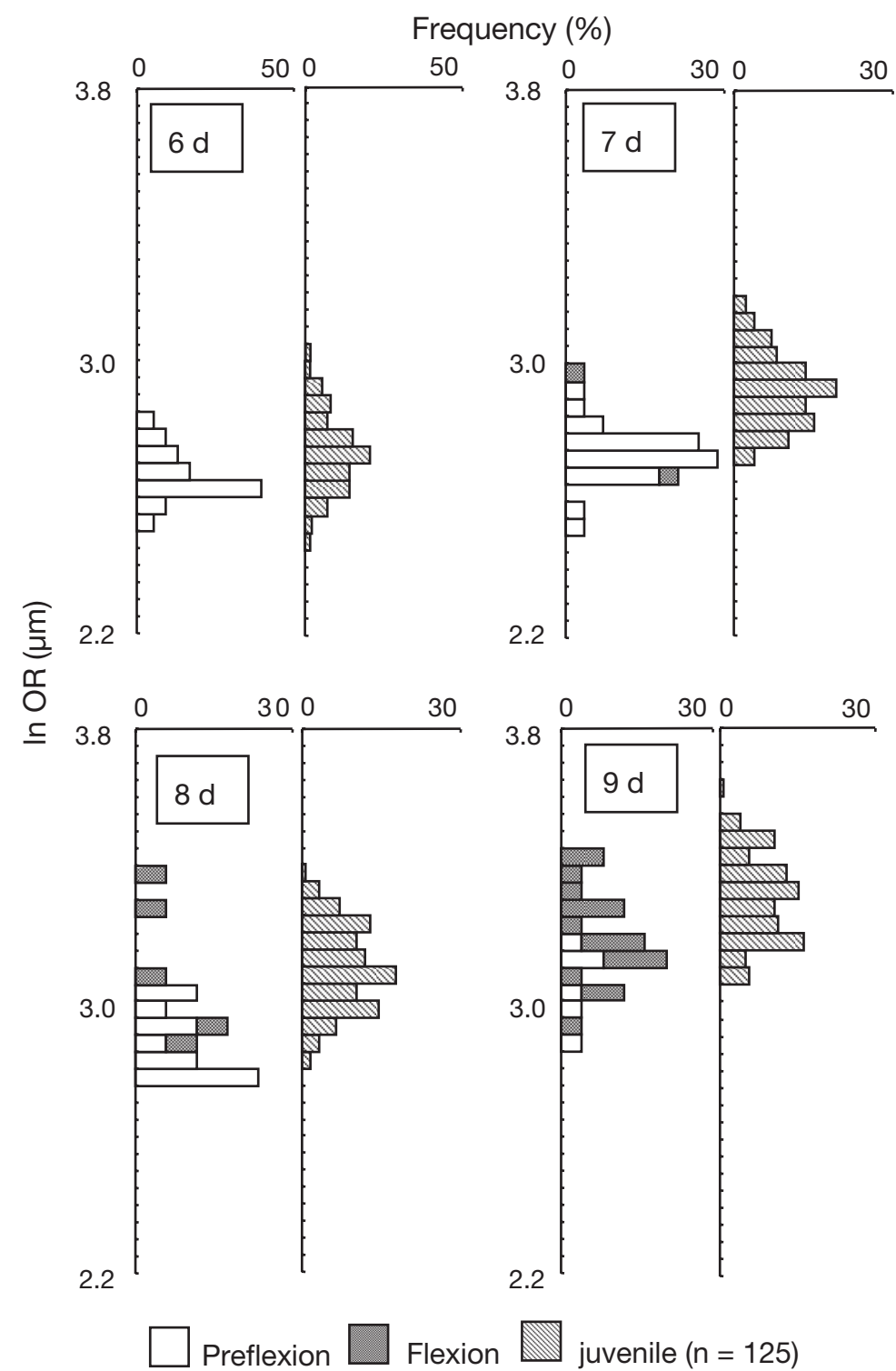

Fig. 8. Thunnus orientalis. Frequency distributions of $\ln$ OR (otolith radius) in juvenile bluefin tuna at 6, 7, 8 and $9 \mathrm{~d}$ and larval bluefin tuna in the preflexion and flexion phases at $6,7,8$ and $9 \mathrm{~d}$. No. of larvae examined in each age class shown in Fig. 4
Watanabe 2004). The feeding success of larval tuna at the 2 specific sizes could be responsible for growth retardation. The first feeding by larval Pacific bluefin tuna occurs at Day 3 to 4 and at size $3.3 \mathrm{~mm}$ SL (Kaji et al. 1996, Itoh et al. 2000). At this size, larvae feed mainly on copepod nauplii (Uotani et al. 1990). The growth retardation that occurred in larvae smaller than $4 \mathrm{~mm}$ SL in the preflexion phase may have been due to an insufficient food intake during the first feeding. The relative growth of the head length, mouth size and body depth of larval Pacific bluefin tuna changes at approximately $5 \mathrm{~mm}$ SL (Uotani et al. 1990, Miyashita et al. 2001); furthermore, the pharyngeal teeth differentiate at this size (Miyashita et al. 1998). Corresponding to these morphological changes, a shift in feeding habit was observed at $5 \mathrm{~mm}$ SL, from small zooplankton (copepod nauplii) to larger zooplankton (copepods of Corycaeus spp.), and larvae $>5 \mathrm{~mm}$ SL were found to have lower rates of empty stomachs and higher amounts of food items per stomach than larvae <5 mm SL (Uotani et al. 1990). Thus, morphological and ecological changes occur at $5 \mathrm{~mm} \mathrm{SL}$, and larvae that succeed in the shift in feeding habits at this size possibly grow faster and develop into the postflexion phase.

The growth rate of larval southern bluefin tuna is positively correlated with the feeding rate but not with temperatures ranging between 27.3 and $27.7^{\circ} \mathrm{C}$ (Jenkins et al. 1991). In the present study, water temperature at the sampling stations ranged from 25.0 to $28.8^{\circ} \mathrm{C}$. There were significant differences in back-calculated SL only on Day 7 (posthatching) between the stations with lower (25.0 to $26.6^{\circ} \mathrm{C}$ ) and higher $\left(27.2\right.$ to $28.8^{\circ} \mathrm{C}$ ) water temperatures; however, these water

Table 3. Thunnus orientalis. Logarithm of otolith radius (ln OR) at ages of larval tuna in the preflexion, flexion and postflexion phases and juvenile bluefin tuna. Percentages of larvae within the ln OR ranges of juvenile bluefin tuna are calculated

\begin{tabular}{|c|c|c|c|c|c|c|c|}
\hline \multirow{2}{*}{$\begin{array}{l}\text { Age } \\
\text { (d) }\end{array}$} & \multicolumn{4}{|c|}{ Range of ln OR $(\mu \mathrm{m})$ at age } & \multicolumn{3}{|c|}{$\%$ larvae in the ln OR range of juveniles } \\
\hline & Preflexion & Flexion & Postflexion & Juvenile & Preflexion & Flexion & Postflexion \\
\hline 6 & $2.52-2.85$ & & & $2.47-3.01$ & 100.0 & & \\
\hline 7 & $2.53-2.92$ & $2.67-2.96$ & & $2.64-3.19$ & 73.1 & 50.0 & \\
\hline 8 & $2.75-3.31$ & $2.87-3.37$ & & $2.83-3.35$ & 66.7 & 100.0 & \\
\hline 9 & $2.90-3.17$ & $2.92-3.44$ & & $3.06-3.60$ & 50.0 & 83.3 & \\
\hline 10 & $3.01-3.29$ & $3.07-3.60$ & $3.45-3.53$ & $3.21-3.87$ & 57.1 & 78.4 & 100.0 \\
\hline 11 & $3.06-3.27$ & $3.09-3.87$ & $3.49-3.56$ & $3.44-4.11$ & 0.0 & 52.8 & 100.0 \\
\hline 12 & $3.14-3.52$ & $3.15-3.78$ & $3.51-3.93$ & $3.61-4.36$ & 0.0 & 10.0 & 81.0 \\
\hline 13 & & $3.57-3.76$ & $3.58-4.24$ & $3.76-4.57$ & & 16.7 & 80.0 \\
\hline
\end{tabular}




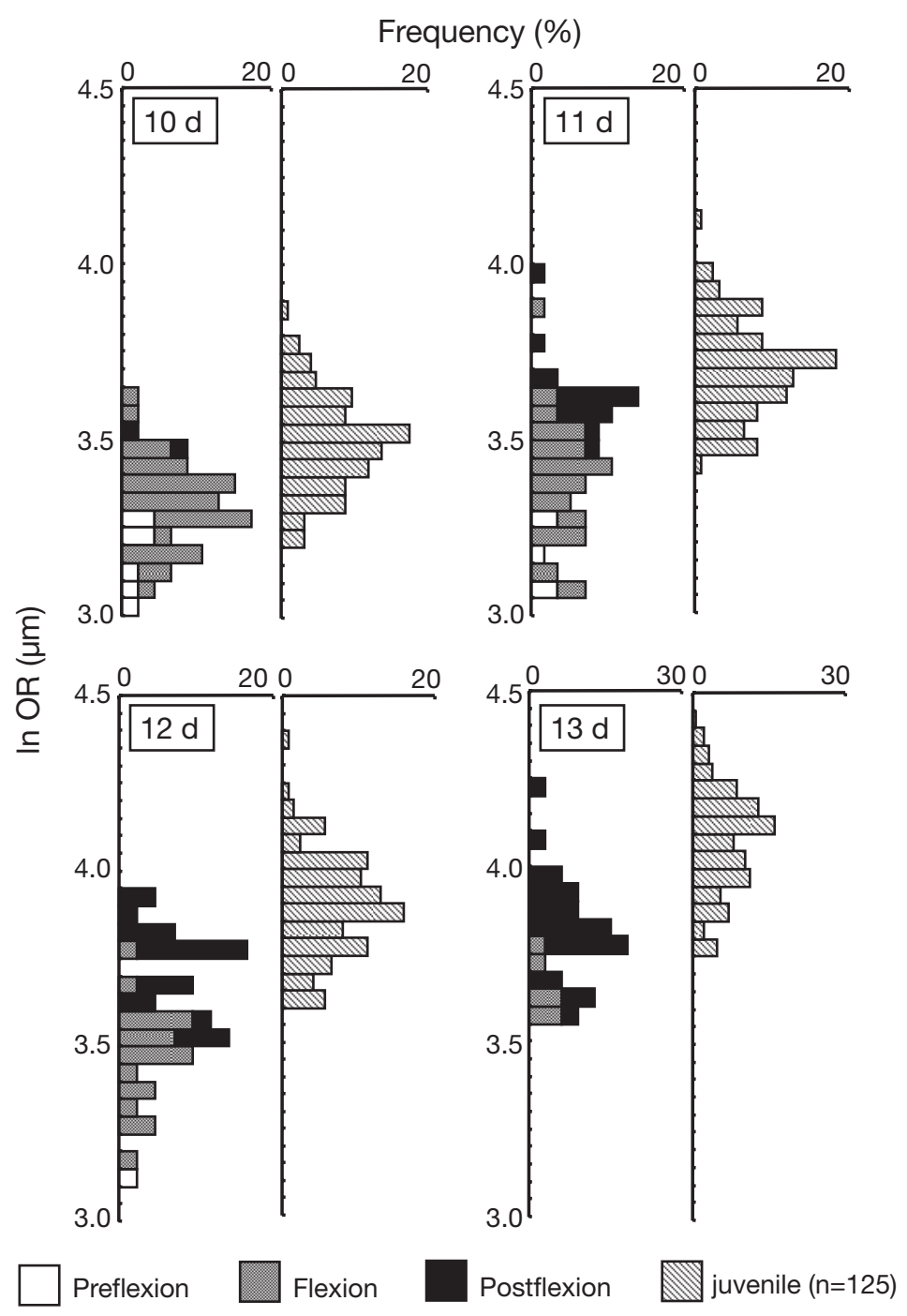

Fig. 9. Thunnus orientalis. Frequency distributions of ln OR in juvenile bluefin tuna at 10,11, 12 and $13 \mathrm{~d}$ and larval bluefin tuna in the preflexion, flexion and postflexion phases at 10,11, 12 and $13 \mathrm{~d}$. No. of larvae examined in each age class shown in Fig. 4

temperatures may not be representative of ambient water temperatures to which larvae were actually exposed. Laboratory experiments are required to examine the effects of ambient water temperature on larval growth.

\section{In 2004 juvenile bluefin tuna originated from the northwestern Pacific Ocean}

Pacific bluefin tuna have 2 distinct spawning grounds. It has been reported that these spawning grounds are formed off the Ryukyu Islands from April to June (Yabe et al. 1966, Ueyanagi et al. 1969) and in the Sea of Japan in August (Okiyama 1974, Kitagawa et al. 1995). The larvae that hatch off the Ryukyu Islands in April to June are transported by the Kuroshio Current, and grow at a rate of ca. 2.7 to $3.3 \mathrm{~mm} \mathrm{~d}^{-1}$ during the juvenile stage (Tanaka unpubl. data), compared with ca. $2.1 \mathrm{~mm} \mathrm{~d}^{-1}$ in cultured Pacific bluefin tuna (Kumai 1997). Juvenile bluefin tuna of 167 to $319 \mathrm{~mm}$ SL (otolith back-calculated age of 54 to $107 \mathrm{~d}$ ) were sampled off the southern coast of Japan. Juvenile bluefin tuna analyzed in the present study had estimated hatch dates between 1 April and 15th June, which in combination with the general south to north flow patterns of the Kuroshio and Tsushima currents (e.g. Nitani 1972) indicated that these fish originated from the spawning grounds off the Ryukyu Islands and not from the Sea of Japan, where spawning occurs later in the year (Okiyama 1974, Kitagwa et al. 1995). Furthermore, the estimated hatch dates of juvenile bluefin tuna corresponded to those of larvae used for comparisons of growth. Accordingly, we conclude that the juvenile bluefin tuna analyzed in the present study were survivors of the cohort of larvae collected off the Ryukyu Islands.

\section{Growth dependent survival of larval bluefin tuna}

The minimum ln OR in each age class of the juvenile bluefin tuna represents the smallest possible size required by larvae for successful recruitment into fisheries resources. The proportion by number of larvae in the preflexion phase within the ln OR range of juvenile bluefin tuna was $100.0 \%$ by Day 6, and this decreased to $0.0 \%$ by Day 11 . These results suggest that larvae in preflexion phase at Day 6 had an opportunity to survive to recruitment but that none of the larvae in the preflexion phase at Day 11 would survive to recruitment. In the flexion phase, this value was $100.0 \%$ at Day 8 but greatly decreased to $10.0 \%$ by Day 12, suggesting that larvae in the flexion phase at an older age had a lower probability of surviving than larvae in the flexion phase at a younger age. The larvae in the postflexion phase had much higher values than those in the preflexion and flexion phase, and thus would have had a greater probability of survival to recruitment. These results indicate that larvae with a more rapid developmental rate have a higher probability of survival to recruitment.

As mentioned above, the results of larval growth history analysis showed that larvae with a high growth 
rate were able to develop to the postflexion phase. Consequently, larvae with high rates of development and growth were able to survive to recruitment, and the developmental rate and growth rate-dependent mortality occurred during the larval stage of Pacific bluefin tuna. The larvae with large ln OR comparable to those of juveniles were very few $10 \mathrm{~d}$ after hatching (Fig. 9). This may be ascribable to the very low density of extremely fast growing larvae in the field. Although we could not collect such extremely fast growing larvae due to their low density, it is speculated that they could appear in the juvenile population because of their very high survival probability.

The probability of survival to recruitment is a function of development in the larval stage in Japanese anchovy Engraulis japonicus: faster growing larvae metamorphosed at a younger age and had a higher probability of surviving to recruitment (Takahashi \& Watanabe 2004). The present study found that growthdependent mortality occurred in the larval stage of Pacific bluefin tuna, as was also shown for Japanese anchovy. In Japanese anchovy, growth and developmental rate-dependent mortality occurred at 50 to $60 \mathrm{~d}$. Growth selective mortality occurred at 41 to $80 \mathrm{~d}$ in Atlantic cod Gadus morhua (Meekan \& Fortier 1996), at 10 to $15 \mathrm{~d}$ in bluefish Pomatomus saltatrix (Hare \& Cowen 1997), at 0 to $5 \mathrm{~d}$ in common coral fish Halichoeres bivittatus (Seracy \& Sponaugle 2001), and at 7 to $10 \mathrm{~d}$ in damselfish Stegastes partitus (Wilson \& Meekan 2002). In the present study, we observed that the growth rate within 2 wk of hatching was crucial for survival to recruitment in Pacific bluefin tuna.

In laboratory experiments, the growth of Pacific bluefin tuna was found to be accelerated after the late larval-juvenile stage (Kaji et al. 1996, Miyashita et al. 2001). Several ecological events will occur subsequent to this period, e.g. metamorphosis and the onsets of piscivory and schooling. We observed the growth and developmental rate-dependent mortality corresponded to the shift of food habit. It is assumed that growth-dependent mortality and/or other mortality processes may also occur during this period, corresponding to ecological events. To better understand the recruitment process and variation in recruitment of Pacific bluefin tuna, further study of the late larval to juvenile stage is required.

Acknowledgements. We are grateful to Captain M. Onoda and the crew of RV 'Shunyo-Maru' for their assistance with field sampling of larval bluefin tuna. We thank Mrs. Y. Niiya, Kochi Prefectural Fisheries Experimental Station, K. Yamamoto, Nagasaki Prefectural Institute of Fisheries, and Taiyo A\&F Co. Ltd. for collecting juvenile bluefin tuna. We also thank Dr. S. Miyashita, Fisheries Laboratory of Kinki University, and Ms. A. Kobayahi, Graduate School of Kyoto University, for their assistance with the assessment of shrinkage of larvae due to ethanol preservation, and Drs. J. Shoji and Y. Yamashita, Field Science Education and Research Center, Kyoto University, for their comments on the manuscript. This study was supported by the Fisheries Agency of Japan and a research fellowship from the Japan Society for the Promotion of Science (JSPS) for Young Scientists (No. 03810). Finally, our manuscript was improved by detailed comments of 3 anonymous referees.

\section{LITERATURE CITED}

Anderson JT (1988) A review of size dependent survival during pre-recruit stages of fishes in relation to recruitment. J Northwest Atl Fish Sci 8:55-66

Bailey KM, Houde ED (1989) Predation on eggs and larvae and the recruitment problem. Adv Mar Biol 25:1-83

Brothers EB, Prince ED, Lee DW (1983) Age and growth of young-of-the-year bluefin tuna, Thunnus thynnus, from otolith microstructure. NOAA Tech Rep NMFS 8:49-60

Campana SE (1990) How reliable are growth back-calculations based on otolith? Can J Fish Aquat Sci 47:2219-2227

Campana SE, Jones CM (1992) Analysis of microstructure data. In: Stevenson DK, Campana SE (eds) Otolith microstucture examination and analysis. Can Spec Publ Fish Aquat Sci 117:73-100

Chambers RC, Miller TJ (1995) Evaluating fish growth by means of otolith increment analysis: spectral properties of individual-level longitudinal data. In: Secor DH, Dean JM, Campana SE (eds) Recent developments in fish otolith research. University of South Carolina Press, Columbia, p 155-175

Collette BB (1999) Mackerels, molecules, and morphology. Soc Fr Ichthyol 25:149-164

Degens ET, Deuser WG, Haedrich RL (1969) Molecular structure and composition of fish otoliths. Mar Biol 2:105-113

Dunkelberger DG, Dean JM, Watabe N (1980) The ultrastructure of the otolithic membrane and the otolith in juvenile mummichog, Fundulus heteroclitus. J Morphol 163: 367-377

Folkvord A, Blom G, Johannessen, A, Moksness E (2000) Growth-dependent age estimation in herring (Clupea harengus L.) larvae. Fish Res 46:91-103

Govoni JJ, Chester JA, Hoss DE, Ortner BP (1985) An observation of episodic feeding and growth of larval Leiostomus xanthurus in the northern Gulf of Mexico. J Plankton Res $7: 137-146$

Hare JA, Cowen RK (1997) Size, growth, development, and survival of planktonic larvae of Pomatomus saltatrix (Pisces: Pomatomidae). Ecology 78:2415-2431

Hovenkamp F (1992) Growth-dependent mortality of larval plaice Pleuronectes platessa in the North Sea. Mar Ecol Prog Ser 58:95-101

Hunter JR (1981) Feeding ecology and predation of marine fish larvae. In: Lasker R (eds) Marine fish larvae. University of Washington Press, Seattle, p 33-77

Itoh T, Shiina Y, Tsuji S, Endo F, Tezuka N (2000) Otolith daily increment formation in laboratory reared larval and juvenile bluefin tuna Thunnus thynnus. Fish Sci 66:834-839

Jenkins GP, Davis TLO (1990) Age, growth rate, and growth trajectory determined from otolith microstructure of southern bluefin tuna Thunnus maccoyii larvae. Mar Ecol Prog Ser 63:93-104

Jenkins GP, Young JW, Davis TLO (1991) Density dependence of larval growth of a marine fish, the southern bluefin tuna, Thunnus maccoyii. Can J Fish Aquat Sci 48: $1358-1363$ 
Kaji T, Tanaka M, Takahashi Y, Oka M, Ishibashi N (1996) Preliminary observations on development of Pacific bluefin tuna Thunnus thynnus (Scombridae) larvae reared in the laboratory, with special reference to the digestive system. Mar Freshw Res 47:261-269

Kendall AW, Ahlstorm EH, Moser HG (1984) Early life stages of fishes and their characters. In: Moser G, Richards WJ, Cohen DM, Fahay MP, Kendall Jr AW, Richardson SL (eds) Ontogeny and systematics of fishes. Am Soc Ichthyol Herpetol Spec Publ 1:11-22

Kitagawa Y, Nishikawa Y, Kubota T, Okiyama M (1995) Distribution of ichthyoplanktons in the Japan Sea during summer, 1984, with special reference to scombroid fishes. Bull Jpn Soc Fish Oceanogr 59:107-114

Kumai H (1997) Present state of bluefin tuna aquaculture in Japan. Suisan Zoushoku 45B:293-297

Lang KL, Grimes CB, Shaw RF (1994) Variations in the age and growth of yellowfin tuna larvae, Thunnus albacares, collected about the Mississippi River plume. Environ Biol Fish 39:259-270

Meekan MG, Fortier L (1996) Selection for fast growth during the larval life of Atlantic cod Gadus morhua on the Scotian shelf. Mar Ecol Prog Ser 137:25-37

Miller TJ, Crowder LB, Rice JA, Marschall EA (1988) Larval size and recruitment mechanisms in fishes: toward a conceptual framework. Can J Fish Aquat Sci 45:1657-1670

Miyashita S, Kato K, Sawada Y, Murata O, Ishitani Y, Shimizu K, Yamamoto S, Kumai H (1998) Development of digestive system and digestive enzyme activity of larval and juvenile bluefin tuna, Thunnus thynnus, reared in the laboratory. Suisan Zoushoku 46:111-120

Miyashita S, Tanaka Y, Sawada Y, Murata O, Hattori N, Takii K, Mukai Y, Kumai H (2000) Embryonic development and effects of water temperature on hatching of the bluefin tuna, Thunnus thynnus. Suisan Zoushoku 48:199-207

Miyashita S, Sawada Y, Okada T, Murata O, Kumai H (2001) Morphological development and growth of laboratoryreared larval and juvenile Thunnus thynnus (Pisces: Scombridae). Fish Bull 99:601-616

Mugiya Y (1987) Phase difference between calcification and organic matrix formation in diurnal growth of otoliths in the rainbow trout, Salmo gairdneri. Fish Bull 85:395-401

Nitani H (1972) Beginning of the Kuroshio. In: Stommel H, Yoshida K (eds) Kuroshio its physical aspects. University of Tokyo Press, Tokyo, p 129-163

Editorial responsibility: Otto Kinne (Editor-in-Chief), Oldendorf/Luhe, Germany
Okiyama M (1974) Occurrence of the postlarvae of bluefin tuna, Thunnus thynnus, in the Japan Sea. Bull Jpn Sea Reg Fish Res Lab 11:9-21

Scott GP, Turner SC, Grimes CB, Richards WJ, Brothers EB (1993) Indices of larval bluefin tuna, Thunnus thynnus, abundance in the Gulf of Mexico; modeling variability in growth, mortality, and gear selectivity. Bull Mar Sci 53: 912-929

Searcy SP, Sponaugle S (2001) Selective mortality during the larval-juvenile transition in two coral reef fishes. Ecology 82:2452-2470

Takahashi M, Watanabe Y (2004) Growth rate-dependent recruitment of Japanese anchovy Engraulis japonicus in the Kuroshio-Oyashio transitional waters. Mar Ecol Prog Ser 266:227-238

Takasuka A, Aoki I, Mitani I (2003) Evidence of growth-selective predation on larval Japanese anchovy Engraulis japonicus in Sagami Bay. Mar Ecol Prog Ser 252:223-238

Tanaka M, Kaji T, Nakamura Y, Takahashi Y (1996) Developmental strategy of scombrid larvae: high growth potential related to food habits and precocious digestive system development. In: Watanabe Y, Yamashita Y, Oozeki (eds) Survival strategies in early life stages of marine resources. AA Balkema, Rotterdam, p 125-139

Ueyanagi S (1969) Observations on the distribution of tuna larvae in the Indo-Pacific Ocean with emphasis on the delineation of the spawning areas of albacore, Thunnus alalunga. Bull Far Seas Fish Res Lab 2:177-256

Uotani I, Saito T, Hiranuma K, Nishikawa Y (1990) Feeding habit of bluefin tuna Thunnus thynnus larvae in the western North Pacific Ocean. Nippon Suisan Gakkaishi 56: 713-717

Watanabe N, Tanaka K, Yamada J, Dean JM (1982) Scanning electron microscope observations of the organic matrix in the otolith of the teleost fish Fundulus heteroclitus (Linnaeus) and Tilapia nilotica (Linnaeus). J Exp Mar Biol Ecol 58:127-134

Wilson DT, Meekan MG (2002) Growth-related advantages for survival to the point of replenishment in the coral reef fish Stegastes Partitus (Pomacentridae). Mar Ecol Prog Ser 231:247-260

Yabe H, Ueyanai S, Watanabe H (1966) Studies on the early life history of bluefin tuna Thunnus thynnus and on the larvae of the southern bluefin tuna T. maccoyii. Rep Nankai Reg Fish Res Lab 23:95-129

Submitted: July 25, 2005; Accepted: January 31, 2006 Proofs received from author(s): July 20, 2006 